\title{
DEPTH OF CURIE TEMPERATURE COMPUTED FROM AEROMAGNETIC ANOMALIES IN SOUTHEASTERN MINAS GERAIS, BRAZIL
}

\author{
G. CORRADO \\ A. RAPOL.LA \\ INSTITUTO DI GEOLOGIA E GEOFISICA UNIVERSITÁ DI NAPOLI \\ LARGO SAN MARCELINO, 10 - NAPOLI - ITALY \\ ON LEAVE OF ABSENCE FROM INSTITUTO DI GEOLOGIA E \\ GEOFISICA UNIVERSITA DI NAPOLI - ITALY \\ P. GASPARINI \\ M.S.M. MANTOVANI \\ INSTITUTO ASTRONÔMICO E GEOFÍSICO UNIVERSIDADE DE \\ SÃo PAULO \\ CAIXA POSTAL - 30.627 - 01000 - SÃO PAULO - BRAZIL
}

This work utilizes an aeromagnetic survey carried out by Prakla and $D N P M$ in the area between $18^{\circ}$ and $21^{\circ} \mathrm{S}, 40^{\circ}$ and $45^{\circ} \mathrm{W}$. By means of a digital filtering, anomalies with wavelength longer than $80 \mathrm{~km}$ were selected. These anomalies are related to the

\section{ABSTRACT}

bottom of the crustal magnetized layer. This represents the surface where ferrimagnetic minerals contained in crustal rocks reach their Curie Temperature. The computation of the morphology of the Curie Temperature was carried out by inverting the data with two-dimen- sional models of arbitrary shape. The best fitting model is obtained by iterative processes. A depth of 22-27 Km was computed for the Curie isotherm in this area. It probably corresponds to a vertical compositional variation within the crust.
$O$ presente trabalho utiliza o levantamento aeromagnético efetuado pela Prakla para o DNPM entre $18^{\circ}-21^{\circ} S e$ $40^{\circ}-45^{\circ} \mathrm{W}$. Utilizando uma filtragem numérica, foram isoladas as anomalias com comprimento de onda superior a $80 \mathrm{~km}$. Estas anomalias são correlacionáveis à morfologia do limite infe-

\section{RESUMO}

rior da camada crustal magnetizada. Este limite é representado pela temperatura de Curie dos minerais ferromagnéticos presentes nas rochas da crosta superior. A determinação da morfolo. gia da temperatura de Curie é efetuada utilizando técnicas de computação ba- seadas em modelos bi-dimensionais de forma qualquer. $O$ modelo que melhor se adapta é obtido por processos iterativos. Foi obtido um valor de 22- 27 $\mathrm{km}$ de profundidade para a tempera. tura de Curie, que provavelmente corresponde a uma variação vertical na composição da crosta.

\section{INTRODUCTION}

A very detailed aeromagnetic survey was carried out in the States of Minas Gerais and Espirito Santo by the German company Prakla and the Brazilian Companhia de Pesquisa de Recursos Minerais (CPRM), under the sponsorship of the agreement for scientific cooperation between Brazil and Germany. The survey consisted E-W profiles flown with a spacing of $2 \mathrm{~km}$, with one check profile every 20 $\mathrm{km}$. The average flight altitude was $400 \mathrm{~m}$ above ground level. Total intensity of the geomagnetic field was measured by Geometrics, G 803, proton magnetometers. Aeromagnetic data were reduced to the year 1971.5 and to a flight altitude of 1200 m.a.s.l. They were made available by Departamento Nacional de Produção
Mineral (DNPM) in the form of 1:100,000 total intensity anomaly field maps.

The substract normal field was the International Geomagnetic reference Field evoluated for the year 1971.5.

The anomaly maps have already been utilized for estimates of the depth to the top of magnetized bodies producing some prominent anomalies and for attempts of correlations with broad geological structures (BOSUM, 1973; FERREIRA and CAVALCANTE, 1978).

In this paper an interpretation of the long wavelength components of the anomalous field in the area between $18^{\circ}$ and $21^{\circ} \mathrm{S}, 40^{\circ}$ and $45^{\circ} \mathrm{W}$ is attempted. The choice of the area was dictated by the existence of a preliminary crustal model, obtained from gravity and seismic surveys (BLITZKOW et al., 1978; GIESE, 1975) which can be used as a reference for the interpretation of aeromagnetic data.

The aim of this paper is to compute the thickness of the crustal magnetized layer. Over such a wide area, the bottom of this layer can be assumed to represent the surface where the Curie temperature of ferrimagnetic minerals occurring in crustal rocks is reached. The knowledge of the depth of this surface and its variations in different structural environments is of obvious interest for the geophysical modelling of the continental crust. 
GEOLOGICAL OUTLINE

The investigated area $\left(18^{\circ}-21^{\circ} \mathrm{S}\right.$, $40^{\circ}-45^{\circ} \mathrm{W}$ ) is located in the Southeastern part of the State of Minas Gerais and the Northern part of the State of Espirito Santo. From a geological point of view in includes the Southern part of São Francisco craton, as defined by ALMEIDA (1977), and the metasediments, high and medium grade metamorphic rocks which adjoin it to the East. The latter iron-rich metasediments (itabirites), of unk nown thickness.

A crustal model of a part of this area $\left(18^{\circ}-20^{\circ} \mathrm{S}, 42^{\circ}-44^{\circ} 30^{\circ} \mathrm{W}\right)$ was computed from gravity data (BLITZKOW et al., 1978) (Fig. 2). The model utilizes also the informations from an unreversed deep seismic profile (GIESE, 1975). The normal crustal thickness is $38-40 \mathrm{~km}$, and a NNE elongated strip where the crust thickens to $45 \mathrm{~km}$ occurs E of São

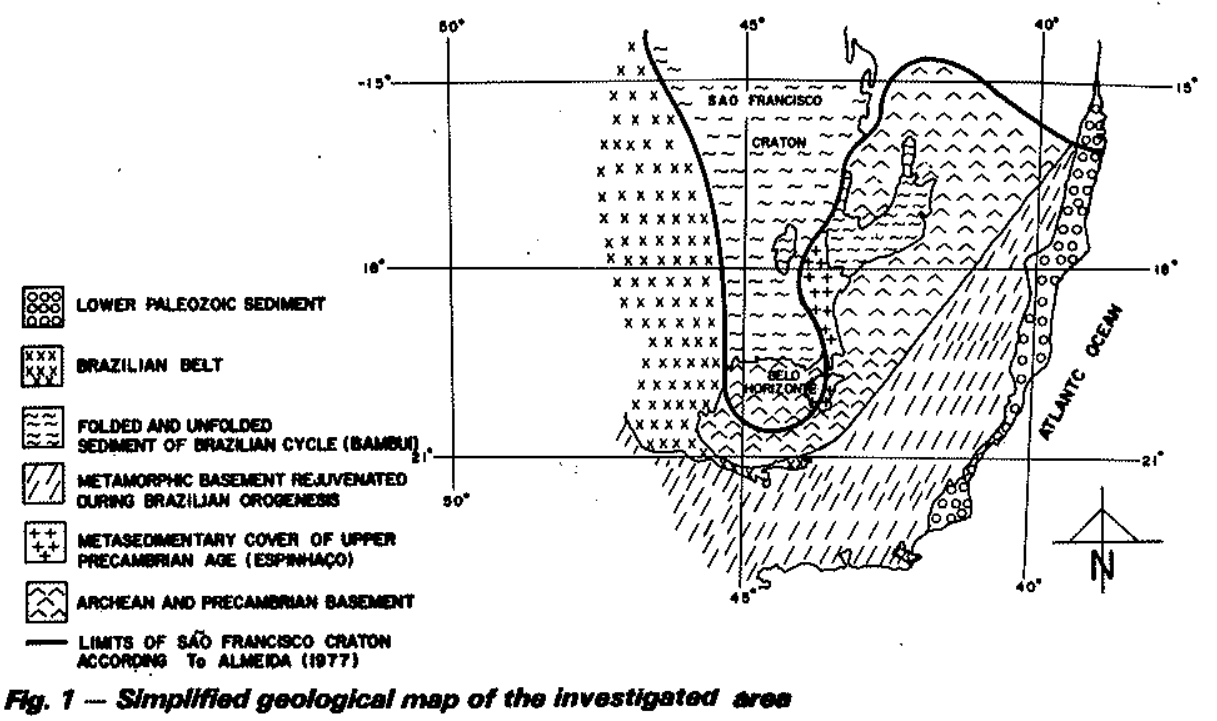

Fo. 1 - Simplified geological map of the investigated area

are mostly granulite grade rocks with composition ranging from very acidic $\left(\mathrm{SiO}^{2}>70 \%\right)$ to mafic terms of gabbroic composition, amphibolites interlayered with biotite and garnet gneisses and kinzingitic gneisses. Most of these rocks were formed during the Trans-Amazonian orogenesis $(2,000$ 2,600 m.y.) (CORDANI et al., 1973). A NNE trending cover of metasedimentary rocks which were deposited on a continental platform in Upper pre-Cambrian (Espinhaço formation) outcrops just E of São Francisco craton. Most of the southern part of the craton is covered by sedimentary formations of late pre-Cambrian to EoCambrian age. In fact the craton acted as a foreland during the latest orogeñic event which affected this area, the Brazilisn orogenesis $(600$ 650 m.y.) (CORDANI et al., 1973). Its western and southern margins are covered by continental platform marine sediments deposited during the Brazilian orogenic cycle (Bambuí formation). A major thrust fault separates the Bambuí formation from the Espinhaço formation, the latter having overridden the former one. The folded sediments and metamorphic rocks forming the $N$ striking Brazilian bett border the craton at W.

Many small mafic and ultramafic (kimberlitic) instrusions cut the rocks of Espinhaco formation. The southern edges of São Francisco craton are covered by pre-Cambrian
(GIESE, 1975). Although the model is not well defined for the lower crust, gravity and seismic data indicate that the lowermost crust is likely to be composed of high grade metamorphic rocks of mafic composition.

\section{COMPUTATIONAL PROCEDURES}

Traditionally, geophysicists are interested in the estimate of the depth to the top of magnetized bodies. The computation of the depth to the bottom of maghetized bodies has received comparatively less attention and it is much more cumbersome.

If one wishes to estimate the depth where the crustal looses its magnetization, the first problem, once that the primary (or normal) field of nuclear origin has been properly subtracted, is the selection of the anomalies to be used for this purpose. The first serious attempts (VAC QUIER and AFFLECK, 1941; BHATTACHARAYA and MORLEY, 1965) estimated the depth of the Curie temperature in the crust by computing the depth to the bottom of a large number of individual anomalies. This was accomplished by comparing individual anomalies with the theoretical fields produced by vertical sided prisms. This method has an unsatisfactory resolution, and it can give only upper limits because the computed depth to the bottom decreases with increasing slope of the magnetized body.

BHATTACHARAYA and LEU (1975) and BYERLY and STOLT (1977) analyzed individual anomalies upper crust values $\left(V_{p}=6.5-6.8\right.$ $\mathrm{km}$. $\left.\mathrm{sec}^{-1} ; \mathrm{Gog}=2.9 \mathrm{~g} . \mathrm{cm}^{-3}\right)$ and sug-

rallel to its $\mathrm{E}$ border. Gravity and rocks with uniform physical characteristics $(\mathrm{Vp} \approx 6.2 \mathrm{~km}$. $\mathrm{sec}-1, \sigma-2.8 \mathrm{~g}$. $\mathrm{cm}^{-3}$ ) occur down to a depth of at least $25 \mathrm{~km}$. P-wave velocity and den-

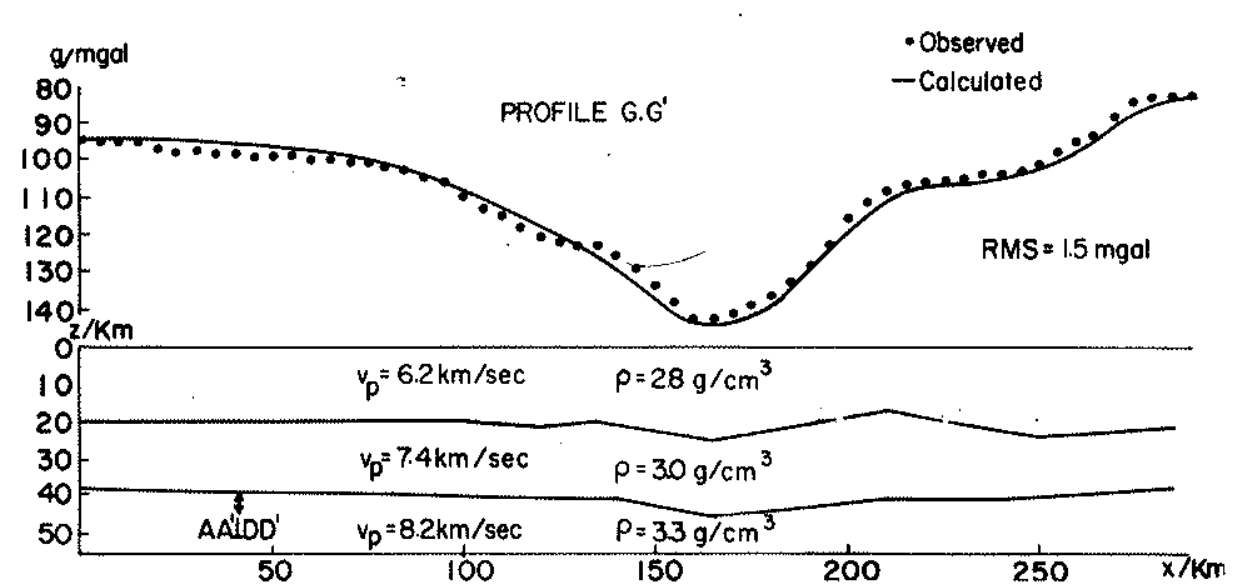

Fig. 2 - Crustal model derived from gravity data along profile G.G' of Fig. 3 from BLITZ KOW ot al., 1978)

gest a very acidic composition for the upper and intermediate crust. For crustal depths greater than $25 \mathrm{~km}$, the gravity model assumes a layer with an average density of $3.0 \mathrm{~g} . \mathrm{cm}^{-3}$. On the other hand, seismic refraction data suggest a continuous increase of $V_{p}$ from 6.2 to $8.2 \mathrm{~km}$. sec -1 , with an average value around $7.4 \mathrm{~km} . \mathrm{sec}^{-1}$ with an improved computational method. The computation of the depth to the bottom was based on the Fourier spectrum of the theoretical fields produced by bodies of regular geometry.

All the methods based on the analysis of individual anomalies suffer of the suspicion that the bottom of the 
magnetized body may not be the surface where the Curie temperature is reached, but it can be the physical boundary of the magnetized body. The analysed anomalies are in fact due to stocks, plutons or metamorphic formations of high susceptibility. In many cases these bodies do have a finite thickness of some $\mathrm{km}$ and do not continue indefinitely downward within the crust. This is particularly true in ancient folded belts where many plutons are emplaced by obduction and are therefore unrooted.

The method use in this paper is similar (although less sophisticated from a statistical point of view) to that described by SHUEY et al. (1977) and SMITH et al. (1977), being partly based on a power spectrum analysis of the whole geomagnetic anomaly field. This method relies on the assumption that the longest wavelength geomagnetic anomalies over an area of some hundred thousands $\mathrm{km}^{2}$ are due to oscillations of the bottom of the magnetized crustal layer. It is then possible to model the magnetized crustal layer as a poligonal two-dimensional body, whose top coincides with the ground level and the bottom, of arbitrary shape, is computed from the longest wavelength anomaly field.

The computation of the depth to the bottom of the magnetized layer was made according to the following steps: procedure has removed most of the shallow effects. The field is remarkably disturbed in the Western part of the area, where the Quadrilatero Ferrifero iron rich sediments outcrop A strong anomaly is in particular as sociated with the area of outcrop of these sediments. The prominence and extension of these anomalies inhibits any reliable analysis of the longest wavelength field in this area. Only the Eastern half, where the regiona trends area very regular and little disturbed, was utilized to compute the bottom of the magnetized layer.

b) the power spectrum of the field reported in Fig. 3 was computed (Fig. 4). It has the typical shape which would result from a combination of

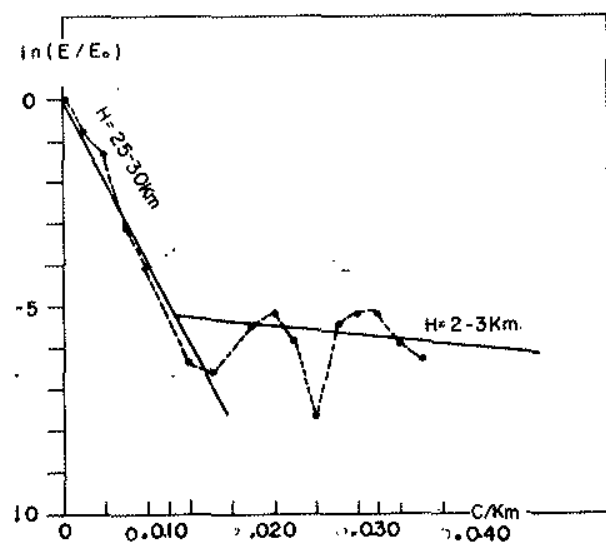

Fig. 4 - Power apectrum of the fiold reported in Fig. 3. H represents depths to the fop of megnetic bodies estimated as indicated by SPECTOR and GRANT (1970)

deep-seated sources and shallow sour-

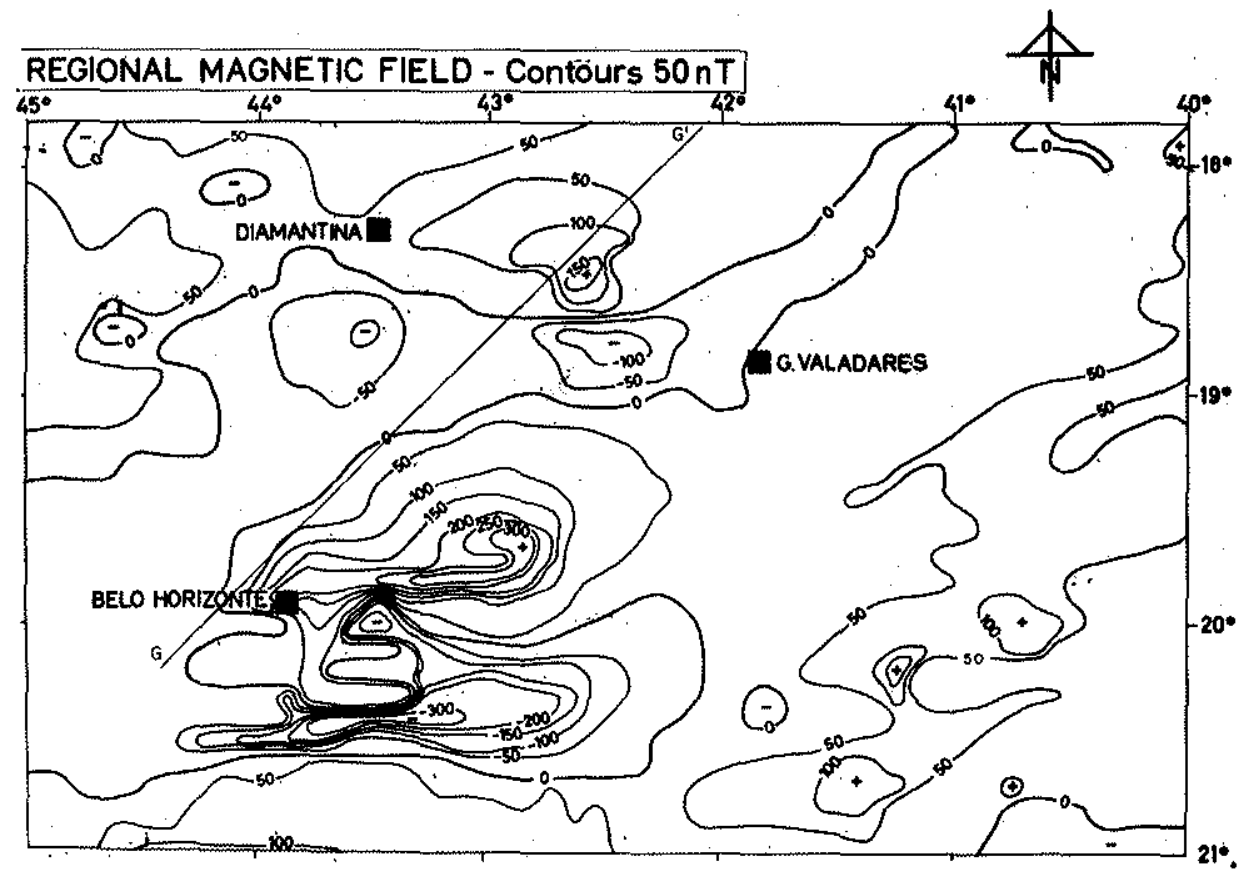

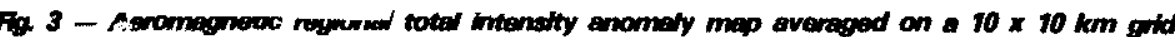

ned. It shows a predominant $\mathrm{NE}$ trend of magnetic anomalies which cut the principal structures of the area, indicating that this averaging

Revista Brasileira de Geociências volume 9 sis of the decay of the power spectrum (SPECTOR and GRANT, 1970) furnishes an average depth of 25 . 30 $\mathrm{km}$ for the deepest sources and of 2 $3 \mathrm{~km}$ for the shallow ones.

c) on the basis of the power spectrum a digital low pass filter with cut off at 0.013 cycles per $\mathrm{km}(\lambda=80$ $\mathrm{km}$ ) was considered adequate to residuate the longest wavelength components of the anomalous field.

d) the residual map reported in Fig. 5 was obtained. It still shows a strong anomaly in correspondence of the Quadrilatero Ferrifero. Profiles A-A' and B-B' were chosen for the computation of the Curie depth.

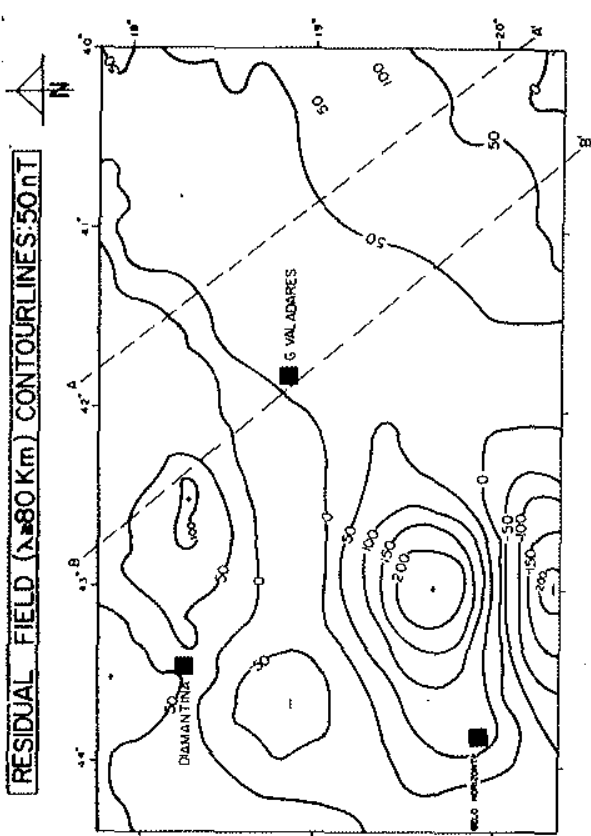

Fig. 6 - Residual anomw/y map $(80 \mathrm{~km})$

e) profiles A-A' and B-B' were inverted using a computer FORTRAN IV program, which computes the theoretical field produced by poligonal two-dimensional bodies of arbitrary shape. The programm uses iterative procedures to adjust the contours and the susceptibility of the model until the theoretical field best fits the experimental field. The utilized model is that of a body of uniform susceptibility whose top surface coincides with the ground level and the bottom surface must be modelled. The models reported in Fig. $6(a$ and $b)$ were obtained. The fit of theoretical to experimental field is very satisfactory, the standard deviation being about $2 \mathrm{nT}$ (profile A-A') and $6 \mathrm{nT}$ (profile B-B')

\section{DISCUSSION ABOUT THE CURIE TEMPERATURE}

The best fitting models indicate that the depth of the Curie temperature decreases Westward, in the investigated area. Depths of $25-27 \mathrm{~km}$ were in fact computed along profile 


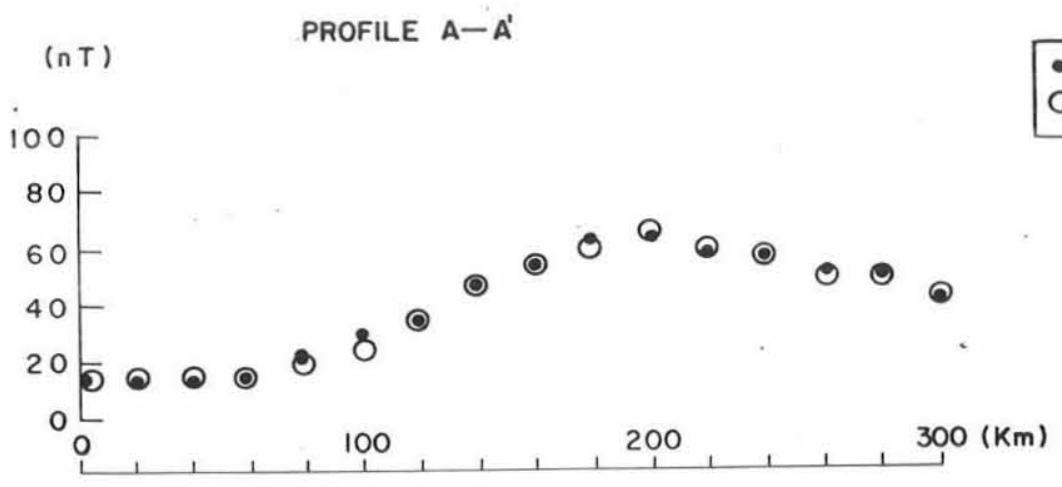

Observed Computed
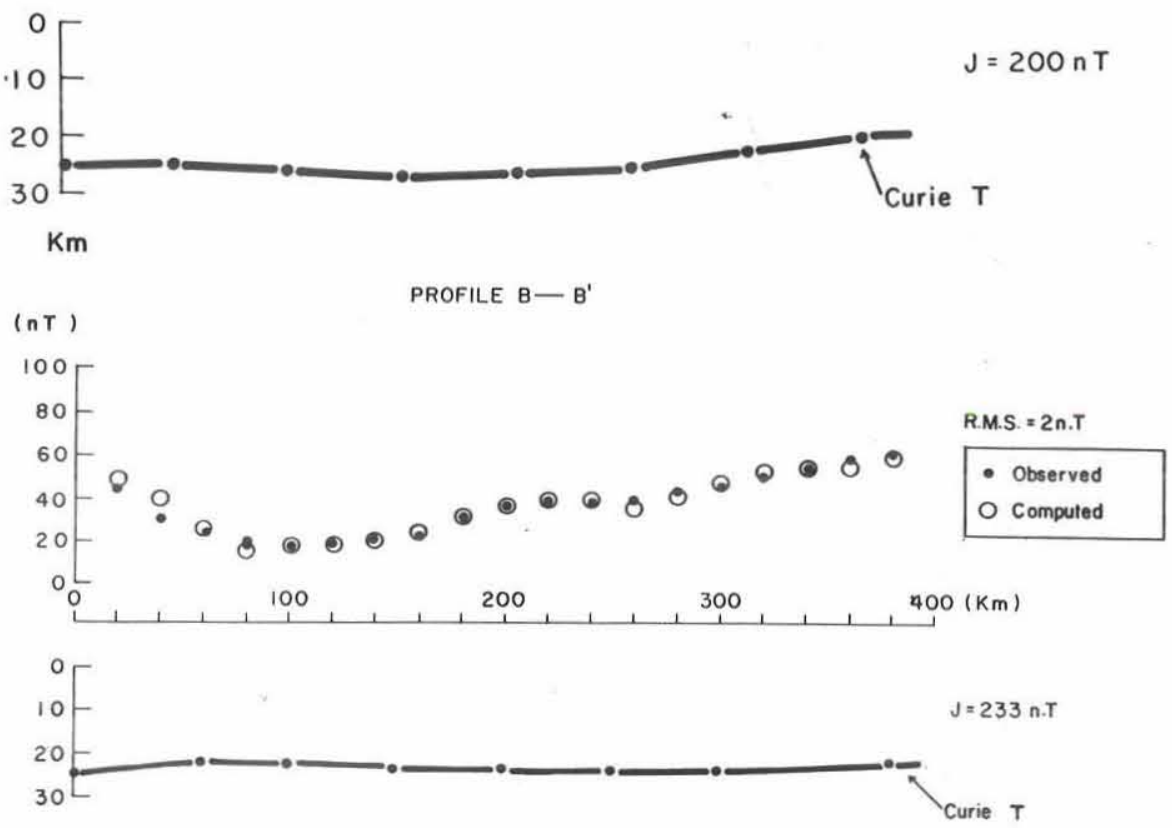

$\mathrm{Km}$

Fig. 6 - Best fitting models computed for profile $A-A^{\prime}$ (a) and 'B-B' (b) of Fig. 5 .

A-A', whereas the computed depths were 22 - $24 \mathrm{~km}$ along profile B-B'. A tendency toward highen depths in the central part of the profile is apparent in both cases. The crustal model derived from gravity and seismic data just W of this area (BLITZKOW et al., 1978 ) indicates that the crust thickens Westward as far as the Eastern border of São Francisco craton. The depth of Curie temperature seems therefore to be inversely related with the crustal thickness, indicating that it is not affected at all by any heat coming from the Upper Mantle.

As mentioned before, gravity and seismic data consistently indicate that the crust must have an average acidic composition at least down to a depth of $25 \mathrm{~km}$. The average crustal intensity of magnetization computed for the models is around $200 \mathrm{nT}$, corresponding to a susceptibility of $8-9 \times 10^{-3}$. This value is fairly high compared to the susceptibilities usually reported in the literature for acidic igneous rocks $\left(10^{-5}-3 \times 10^{-3}\right)$. However the computed average susceptibilities are not unpossible in the continental upper and intermediate crust. Susceptibilities of this order were in fact measured in very acidic charnockitic granulite facies rocks outcropping along the nerals of the hematite $\left(\alpha \mathrm{Fe}_{2} \mathrm{O}_{3}\right)-$ ilmenite $\left(\mathrm{FeTiO}_{3}\right)$ solid solution series. Anyway most of the members of the latter series are ferrimagnetic and have a very low saturation magnetization (e.g. saturation magnetization of hematite is 0.5 emu. $\left.\mathrm{g}^{-1}\right)$. They therefore do not contribute strongly to the anomalous fields created bv crustal rocks. The saturation magnetization of the members of the magnetite-ulvospinel series is much higher and it is directly dependent on the magnetite content. The latter has a saturation magnetizations of 92 emu.g-1. Magnetic susceptibility also increases as a function of magnetite content. The Curie temperature of the members of this series change with continuity between the limits of $580^{\circ} \mathrm{C}$ (Curie temperature of magnetite) and $-153^{\circ} \mathrm{C}$ (ulvospinel). The composition of minerals of this series occurring in rocks depends on several factors, including the composition of the liquid it crystallized from, the oxygen fugacity, the temperature of crystallization, etc. Generally, acidic igneous rocks contain fairly pure magnetite, whereas mafic rocks contain terms of intermediate composition. Acidic and mafic rocks have therefore also different Curie temperatures. Furthermore different Curie temperatures have been measured in mafic magmas of alkali-basaltic and tholeiitic compositions. Alkali-basalts contain intermediate composition members of the magnetite-ulvospinel series with Curie temperatures in the range $200-300^{\circ} \mathrm{C}$, whereas tholeiites contains almost pure magnetite with Curie temperature around $550-580^{\circ} \mathrm{C}$ (ROBERTI and SCANDONE, 1975). This is a consequence of the fact that magnetite is a late crystallizing mineral in tholeeitic liquids and is therefore formed at shallow depth. Chemical processes affecting the crustal rocks may decrease the overall susceptibility of the rock, because produce important changes of the ferrimagnetic phases (HAGGERTY, 1978). High temperature $\left(\sim 600^{\circ} \mathrm{C}\right)$ oxidation may occur in the continental crust at least down to amphibolitic facies levels during rifting or orogenic phenomena. It will produce the exsolution of a ironrich ferrimagnetic phase with high susceptibility and an ilmenite of intermediate composition. Maghemite' $(\gamma$ $\mathrm{Fe}_{2} \mathrm{O}_{3}$ ) is produced by low temperature oxidation from magnetite-ulvospinel minerals. Maghemite has a Curie temperature of $545^{\circ} \mathrm{C}$, but it is unstable at temperatures between $250^{\circ} \mathrm{C}$ and $550^{\circ} \mathrm{C}$, and readily transforms into ferrimagnetic low susceptibility hematite. The net effect of the processes is therefore a decrease of susceptibility of the rock. An even sharper decrease of susceptibility is produced by metasomatic processes, 
which usually transform ferrimagnetic minerals of the magnetite-ulvospinel series into paramagnetic minerals. Granulite facies rocks of acidic composition have magnetite-rich phases which produce a high average susceptibility of the rock. A typical saturation magnetization versus temperature curve for a very acidic granulite $\left(\mathrm{SiO}_{2}\right.$ $>70 \%$ ) is reported in Fig. 7. Chemical analysis and mineralogical descriptions of this rock can be found in GASPARINI and MANTOVANI (1978). The saturation magnetization curves show a prominent phase with Curie temperature around $550^{\circ} \mathrm{C}$ (almost pure magnetite) and one sample shows a tail at $700^{\circ} \mathrm{C}\left(\alpha: \mathrm{Fe}_{2} \mathrm{O}_{3}\right)^{\prime}$ probably produced by transformation of maghemite.

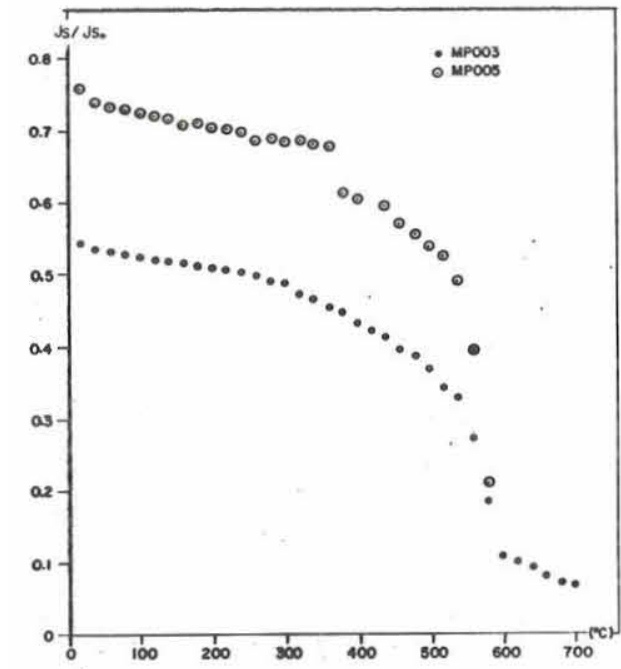

r.v. 7 - Saturation magnetuzation vs. rempe
rature curves for two samples of acidic charnockites

Still higher Curie temperatures can be produced by serpentinization processes of mafic rocks with the reduction of iron oxides (HAGGARTY, 1978).

This discussion shows that different depths of Curie temperature will be found if lateral variations of chemical composition occur in the continental crust. As it is not possible, without the support of independent arguments, ot distinguish whether a variation of the depth of Curie temperature is due to lateral changes of temperature or of composition, the surface where the Curie temperature is reached cannot be considered "a priori" as an isotherm. However, in general high Curie temperatures (500 $580^{\circ} \mathrm{C}$ ) are to be expected where acidic rocks predominate, whereas Curie temperatures as low as $200-250^{\circ} \mathrm{C}$ can be expected where mafic rocks predominate.

The depths of Curie temperature computed for Southeastern Minas Gerais $(22-27 \mathrm{~km})$ are in the range of the "normal" depths up to now inferred for different continental areas unaffected by recent orogenic or volcanic phenomena. Depths of $16-20$ $\mathrm{km}$ were computed for Utah High Plateaus and of $15-31 \mathrm{~km}$ for Uinta Basin of Utah (SHUEY et al., 1977). Normal depths of about $20 \mathrm{~km}$ were computed by BYERLY and STOLT (1977) for Northern and Southern Arizona. An average depth of $20 \mathrm{~km}$ was computed for typical continental areas by VACQUIER and AFFLECK (1941). If a linear temperature gradient is assumed within the continental crust in areas with normal gradients, temperatures in excess of $600^{\circ} \mathrm{C}$ are to be expected at depth greater than $20 \mathrm{~km}$. The temperature gradient in Southeastern Minas Gerais is about $15^{\circ} \mathrm{C} \cdot \mathrm{km}^{-1}$ (USSAMI et al., 1978), so that linear extrapolation would lead to temperatures of about $380^{\circ} \mathrm{C}$ at $25 \mathrm{~km}$ of depth. A linear temperature gradient is however not possible within the continental crust. The constraints imposed by the balance between radiogenic heat production measured in the outcropping rocks and observed heat flow requires that radioactive elements have to be greatly concentrated in the uppermost $\mathrm{km}$ of crust. Geochemical arguments support this contention (HEIER, 1965). Thermal models of continental crust with different upward concentrations of radioactive elements have been computed (HYNDMANN i et al., 1968; LACHENBRUCH, 1968). According to these models, the temperature gradient decreases sharply with depth and, in shield areas, the temperature at the base of the crust appear to be in the range $350-500^{\circ} \mathrm{C}$ (Fig. 8). Heat flow measured in Southern Minas Gerais is compatible with these temperature profiles (USSAMI et al., 1978). Although the concentrations of radioactive elements measured in some acidic high grade metamorphic rocks of granulite facies indicate that radioactive elements concentrations may not decrease with depth as sharply as generally assumed, a maximum increase of 50 . $80^{\circ} \mathrm{C}$ is to be expected over the above reported profiles (GASPARINI and MANTOVANI, 1978). These data hence show that, if Curie temperature of crustal rocks are about $500^{\circ} \mathrm{C}$, the Curie temperature will be reached in the Upper Mantle. In this case the nigh susceptibility and saturation magnetization of ultramafic rocks will cause prominent long wavelength magnetic anomalies associated with oscillations of the crust-upper mantle boundary. No evidence of this has been found. The depth of Curie temperature in Southeastern Minas Gerais coincides approximately with the depth of the top of the lower crustal layer, having a density of 3.0 g. $\mathrm{cm}^{-3}$, as computed by gravity data. This layer is probably

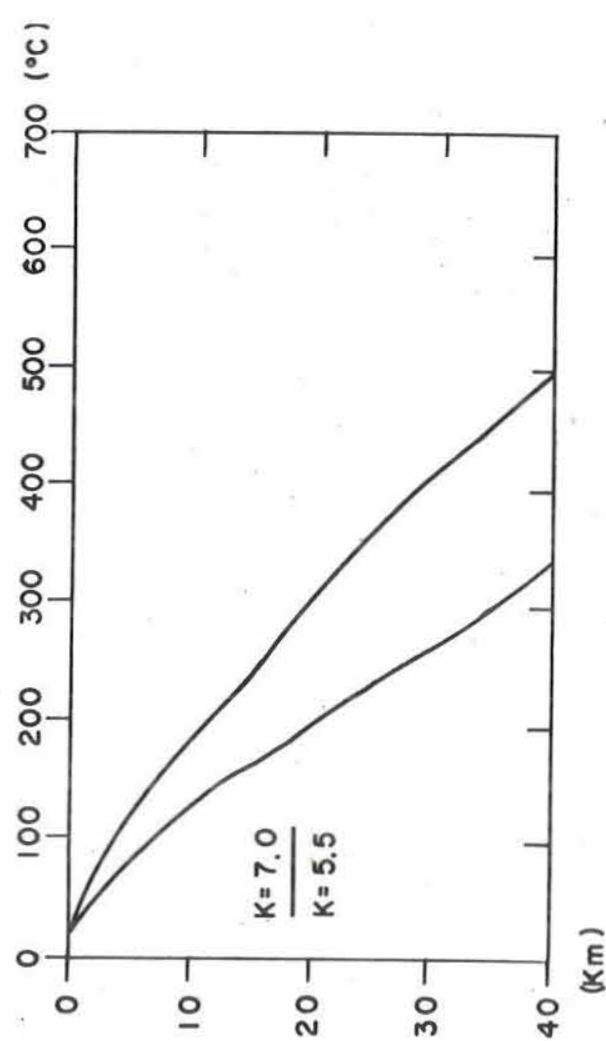

Fig. 8 - Typical temperature protives in shield areas firom MYNDMAN ot al., 1978. $K$ indicates the used thermal conductivities. The lines represent the possible ranges of temperature at each depth.

a schematization of a situation where a gradual change of physical characteristics occurs with depth. Anyway, if at this depth the crustal composition changes from acidic to mafic, a sharpe change of Curie temperatures from about $500^{\circ} \mathrm{C}$ to less than $300^{\circ} \mathrm{C}$ may occur. Therefore the magnetized crustal layer will terminate at this boundary, which, in this case, is not an isotherm, but a chemical boundarg. The westward increase of the depth of Curie temperature is consistent with a slight increase of the top of the lower crustal layer computed by gravity.

If this interpretation is correct, the depth of Curie temperature will be almost independent of small variations of the crustal temperature and could be used as a marker for major chemical vertical changes within the crust.

\section{CONCLUSIONS}

The inversion of the longest wavelength components of the Fourier spectrum of aeromagnetic anomalies in Southeastern Minas Gerais and Espirito Santo indicates a depth of 22 - $27 \mathrm{~km}$ for the bottom of the crustal magnetized layer. This can be interpreted as the surface where the ferrimagnetic minerals contained in crustal rocks reach their Curie temperature. Curie temperatures of minerals of the magnetic-ulvospinel solid solution 
series, which are responsible for the main magnetic characteristics of the rocks, change strongly with composition. The latter in turn depends on many factors, such as the composition of the rock, and the chemicalphysical conditions existing at their crystallization. Generally acidic rocks have Curie temperatures around 500 $580^{\circ} \mathrm{C}$. These same temperatures have been measured in metamorphic acidic rocks of granulite facies. Curie tem-

The authors are grateful to the Director of the second District of Departamento Nacional de Produção Mineral, Dr. Maria Helena Teixeira peratures of $200-300^{\circ} \mathrm{C}$ are generally measured in mafic rocks of alkali-basaltic composition.

Thermal models of continental shield areas indicate that temperatures around $500^{\circ} \mathrm{C}$ are found only below the crust-upper mantle boundary. The crust-upper mantle boundary in the investigated area is at a depth of $38-40$ $\mathrm{km}$. The depth computed for the Curie isotherms corresponds fairly well with

\section{ACKNOWLEDGEMENTS}

Mendes, anc' to Dr. Clovis C. de Sá for having made available the aeromagnetic maps.

\section{REFERENCES}

ALMEIDA, F.F. de - 1977 - O craton de São Francisco, Rev. Brasil. Geoc., 7: 349-364.

BHATTACHARAYA, B.K., MORLEY, L.W. 1965 - The delineation od deep crustal mgnetic bodies from total field aeromagnetic anomalies. J. Geomag, Geolec., 17: 237-252.

BHATTACHARAYA, B.K. LEU, L.K. - 1975 - Analysis of magnetic anomalies over Yellowstone National Park: mapping of Curie point isothermal surface for geothermal reconnaissence. J. Geoph. Res., 80: 4416 4465.

BLITZKOW, D., GASPARINI, P., MANTOVANI, M.S.M., SÃ, N.C. de - 1978 - Crustal struclures of Southeastern Minas Gerais, Brazil, deduced by gravity measurements. Rev. Brasil. Geoc. (submetted for publ.).

BOSUM, W. - 1973 - O levantamento aeromagnétıco de Minas Gerais e Espírito Santo e sua sequiência quanto à estrutura geológica. Rev. Brasil. Geoc. 3: 149-159.

BYERLY, P.E., STOLT, R.H. - 1977 - Anattempt to define the Curie point isotherm in Northern and Central Arizona. Geophysics, 42: 1394-1400.

CORDANI, U.G., AMARAL, G., KAWASHITA, K - 1973 - The Precambrian evolution of South América, Geol. Rund., 62: 309-317.
FERREIRA, F.J.F., CAVALCANTE, J.C. 1978 - Integração dos dados aeromagnéticos e geológicos no SW de Minas Gerais. Paper presented at 30th Congresso Brasileiro de Geologia, Recife, november 1978.

GASPARINI, P., MANTOVANI, M.S.M. 1978 - Geochemistry of charnockites from São Paulo State, Brazil. Earth Plan. Sci. Letters (in press).

GIESE, P. - 1975 - Preliminary report on the results of seismic measurements in the Bra zilian coatal moutains march, april 1975 Unpubl, Report Brazil-Germany sci. agreement.

HAGGERTY, S.E. - 1.978 - Mineralogical constraints on Curie isotherms in deep crusta magnetic anomalies. Geophys. Res. Letters, 5: $105-108$

HEIER, K.S. - 1965 - Metamorphism and chemical differentiation of the crust. Geol. Forons. Stock, Fork., 249-256.

HYNDMAN, R.D., LAMBERT, I.B., HEIER, K.S. JAEGER, J.C. RINGWOOD, A.E. 1968 - Heat fow and surface radiactivity measurements in the Precambrian shield of Western Australia. Phys. Earth Plan. Inter. 1: $129-135$

LACHENBRUCH, A.H. 1968 - Preliminary the depth of the top of a lower crustal layer with a density of $3.0 \mathrm{~g} . \mathrm{cm}^{-3}$ and $\mathrm{V}_{\mathrm{p}} \approx 7.4 \mathrm{~km} \cdot \mathrm{sec}^{-1}$. We believe that it corresponds to a compositional boundary where an acidic upper crust characterized by minerals with Curie temperatures around $500-580^{\circ} \mathrm{C}$ grades to a mafic crust containing minerals with Curie temperatures between 200 and $300^{\circ} \mathrm{C}$. This is consistent with the heat flow data available for this region (USSAMI et al., 1978).

This research was partly carried out while one of the authors (PG) was visiting Professor at IAG-USP with a grant from FAPESP no ${ }^{\circ} 77 / 0899$. geothermal model of Sierra Nevada J. Geophys Res., 73: 6977-6989.

ROBERTI, N., SCANDONE, R. - 1975 - Ther momagenetic study of basalts from Southeastern Silicy. Boll. Geofis Teor. Appl., 17 259-264.

SHUEY, R.T., SCHELLINGER, D.K., TRIPP, A.C., ALLEY, L.B. - 1977 - Curie depth determination from aeromagnetic spectra. Geophys. J.R. astr. Soc., 50: 75-101

SMITH, R.B. SHUEY, R.T. PELTON, J.R. BAILEY, J.P. - 1977 - Yellowstone hot stop: contemporary tectonics and crustal properties from earthquake and aeromagnetic data. J. Geophys. Res., 82-3665-3676.

SPECTOR, A., GRANT, F.S. - 1970 - Statistical models for interpreting aeromagnetic data, Geophysics, 35: 293-302.

USSAMI, N., HAMZA, V.M., VITORELLO, I. - 1978 - Modelo geotérmico preliminar da região leste da faixa geotransversal brasileira. Paper presented at the 30 ht Congresso Brasileiro de Geologia, Recife, november, 1978.

VACQUIER, V., AFFLECK, J. - 1941 Computation of the depth to the bottom of the Earth's magnetic crust. Trans. Amer. Geophys. Union, 22nd Annual Meeting, 446 450. 